\title{
Complex Legacies: Materiality, Memory, and Myth in the Arabian Peninsula
}

\author{
Ileana Baird
}

This casket India's glowing gems unlocks, And all Arabia breathes from yonder box.

ALEXANDER POPE, The Rape of the Lock

$(1712-1714 / 15)$

All around the world national and communal identities are increasingly being defined through new readings of their history, and that history is frequently anchored in things.

NeIL MaCgregor, A History of the World in 100 Objects (2010)

In a suggestive passage, Wilfred Thesiger, or, as his Arab friends affectionately called him, Mubarak bin London, described his encounter with the people of the Empty Quarter in the following terms:

"The northern Arabs had no traditions of civilization behind them. To arrange three stones as a fireplace on which to set a pot was the only architecture that many of them required. They lived in black tents in the desert, or in bare rooms devoid of furnishings in villages and towns. They had no taste nor inclination for refinements. Most of them demanded only the bare necessities of life, enough food and drink to keep them alive, clothes to cover their nakedness, some form of shelter

1 Wilfred Thesiger, Arabian Sands (London: Longmans, 1959; Dubai: Motivate Publishing, 1994), 88. Citations refer to the Motivate Publishing edition.

2 Ibn Khaldûn, The Muqaddimah. An Introduction to History, ed. N.J. Dawood, trans. Franz Rosenthal (Princeton, NJ: Princeton University Press, 1967), 118-19. Interestingly, Ibn Khaldûn's account of the desert Bedouins' material life is very similar to Thesiger's: "the inhabitants of the desert

from the sun and wind, weapons, a few pots, rugs, water-skins, and their saddlery. It was a life which produced much that was noble, nothing that was gracious."

This blunt description of the material life of the Arabian Peninsula about 1946-1947, the time when Thesiger crossed the Empty Quarter in the company of his Bedouin guides, shows the place as devoid of any "architecture," "furnishings," or "refinements" - material references seen here, in a similar way to Ibn Khaldûn's much earlier's account in The Muqaddimah, as signs of "civilization." ${ }^{2}$ The detailed list of objects that fill the life of the desert Arabs - pots, rugs, water-skin, saddlery, weapons, tents-depicts a lifestyle of extreme simplicity, where food, drink, garments, and shelter are all that is needed for physical survival in the harsh desert environment. Albeit reductionist, this description is not inaccurate: Thesiger experienced the desert firsthand and he recorded his impressions not only in writing but also visually, in the over 38,00o photographs currently held at the Pitt River Museum in Oxford. However, this depiction is strangely at odds with other accounts of Arabia as a place of breathtaking beauty and magic. Here is a recollection of the same place by Richard F. Burton, nineteenth-century traveler to

adopt the natural manner of making a living, namely, agriculture and animal husbandry. They restrict themselves to the necessary in food, clothing, and mode of dwelling, and to the other necessary conditions and customs. They do not possess conveniences and luxuries. They use tents of hair and wool, or houses of wood, or of clay and stone, which are not furnished (elaborately). The purpose is to have shade and shelter, and nothing beyond that" (92). 
the Arabian Peninsula and remarkable translator of The Arabian Nights:

"[T] he Jinn bore me at once to the land of my predilection, Arabia, a region so familiar to my mind that even at first sight, it seemed a reminiscence of some bygone metempsychic life in the distant Past. Again I stood under the diaphanous skies, in air glorious as ether, whose every breath raises men's spirits like sparkling wine. Once more I saw the evening star hanging like a solitaire from the pure front of the western firmament; and the after-glow transfiguring and transforming, as by magic, the homely and rugged features of the scene into a fairy-land lit with a light which never shines on other soils or seas. Then would appear the woolen tents, low and black, of the true Badawin, mere dots in the boundless waste of lion-tawny clays and gazelle-brown gravels, and the camp-fire dotting like a glow-worm in the village center. Presently, sweetened by distance, would be heard ... the measured chant of the spearmen gravely stalking behind their charge, the camels ... and - most musical of music - the palmtrees answered the whispers of the nigh-breeze with the softest tones of falling water." 3

Through a subtle process of "transfiguring and transforming," the viewer's perspective changes

3 Richard F. Burton, preface to The Arabian Nights. Tales from A Thousand and One Nights, trans. and notes by Richard F. Burton (New York: Modern Library, 2004), xxv-xxvi.

4 The Travels of Ludovico di Varthema in Egypt, Syria, Arabia Deserta and Arabia Felix, in Persia, India, and Ethiopia, A.D. 1503 to 1508, ed. John Winter Jones and George Percy Badger (Farnham: Ashgate, 2010); Joseph Pitts, A True and Faithful Account of the Religion and Manners of the Mahometans (Exon: Printed by S. Farley, 1704); Travels through Arabia and Other Countries in the East, Performed by M. Niebuhr, trans. Robert Heron, 2 vols. (Edinburgh: Printed for R. Morrison and Son, 1792); Travels of Ali Bey in Morocco, Tripoli, Cyprus, Egypt, Arabia, Syria, and Turkey between the Years 1803 and 1807 , Written by Himself, 2 vols. (London: Longman, Hurst, Orme and Brown, 1816); John Lewis Burckhardt, Travels in Syria and the Holy Land (London: J. Murray, 1822) and Travels in Arabia, Comprehending an Account of Those Territories in Hadjaz Which the Mohammedans Regard as from the "homely and rugged" details of everyday life to a "fairy-land scene" of domestic harmony. Tents, clays, gravels, camels, and palm trees are suddenly ensouled through the magical alchemy of light, scent, and sound. No longer just "bare necessities of life," the things that fill this nostalgic landscape gain agency and a story-like quality through emotion and synesthesia, conjuring in the reader's mind Arabia of the soul.

When reading about Arabia, such sharply contrasting descriptions are the norm. The same objects that prove in some accounts the lack of "civilization" and "traditions" of a people whose energies are focused mainly on survival are rendered in other accounts as breathing an unmatched beauty and a profound spirituality. Travelers like Lodovico Varthema in the sixteenth century, Joseph Pitts and Carsten Niebuhr in the eighteenth century, Ali Bey, Johann Ludwig Burckhardt, Richard Burton, Georg Wallin, Carlo Guarmani, Charles M. Doughty, William Gifford Palgrave, and Lady Anne Blunt in the nineteenth century, Wilfred Thesiger, Harold Ingrams, Bertram Thomas, and Harry St. John Philby in the twentieth century, and Marcel Kurpershoek in the twenty-first century ${ }^{4}$ provided detailed depictions of the desert environment, the Bedouin life, or Arabia's holy places through tropes of pilgrimage,

Sacred (London: H. Colburn, 1829); Richard Burton, Personal Narrative of a Pilgrimage to El-Medinah and Meccah, 3 vols. (London: Longman, Brown, Green, and Longmans, 1855-1856); Georg August Wallin, Travels in Arabia (1845 and 1848) (Cambridge: Oleander Press, 1979); Carlo Guarmani, Northern Nejd: Journey from Jerusalem to Anaiza in Kasim (London: Argonaut Press, 1866); Charles M. Doughty, Travels in Arabia Deserta (Cambridge: Cambridge University Press, 1888); W.G. Palgrave, Narrative of a Year's Journey through Central and Eastern Arabia (London: MacMillan, 1865); Lady Anne Blunt, A Pilgrimage to Nejd, the Cradle of the Arab Race (London:J. Murray, 1881); Harold Ingrams, Arabia and the Isles (London: Kegan Paul International, 1998); Bertram Thomas, Arabia Felix: Across the Empty Quarter of Arabia (London:Jonathan Cape, 1932); H. St. J.B. Philby, A Pilgrim in Arabia (London: Golden Cockerel Press, 1943); Marcel Kurpershoek, Arabia of the Bedouins, trans. Paul Vincent (London: Saqi Books, 2001). 
hardship, and discovery. On the other hand, Muslim travelers to the Arabian Peninsula, from Naser-e Khosraw, Ibn Jubayr, Ibn Battuta, and Evliya Çelebi to Nawab Sikandar Begum, Mirzâ Mohammed Hosayn Farâhâni, and Jalāl Âl-e Ahmad, ${ }^{5}$ focused mainly on pilgrims' travels to Mecca, the spiritual and religious endpoint of the Hajj. Although obviously reflecting the sensibility of their authors, these narratives provide unique insights into the material culture of the place, ranging from accounts of the desolate bareness of the environment to Orientalized evocations of a magical and alluring locale. Within this wide variety of impressions, and within the changing waves of history, Arabia's distinctiveness is still to be asserted.

This collection is an attempt to do so by focusing on the things most often associated with the Arabian Peninsula for their perceived value of stable cultural signifiers. Here, incense burners, pearls, dates, protective medallions, al-Sadu weavings, head coverings, jewelry, the saker falcon, and the Gulf oil are set side by side with ancient books, magic lamps, flying carpets, an elusive desert, and myriad other things connoting wealth, magic, and exoticism to assemble through their individual narratives the complex history of a land at the crossroads of civilizations. To suggest this blend of the material and the imaginary, reality and fiction, geography and symbolism that is the distinctive characteristic of the place, we have chosen a title that echoes a line from one of Alexander Pope's famous poems ${ }^{6}$ that metonymically describes Arabia through one of its most representative things: its legendary perfumes. Thus, All Things Arabia as-

5 Naser-e Khosraw's Book of Travels, ed. Wheeler M. Thackston (New York: sunY Press, 1985); The Travels of Ibn Jubair, ed. William Wright (Leyden: E.J. Brill, 1852); The Travels of Ibn Battuta, A.D. 1325-1354: Volume II, ed. H.A.R. Gibb (Abingdon: Routledge, 2017); Evliya Çelebi, Narrative of Travels in Europe, Asia, and Africa, in the Seventeenth Century, trans. Ritter Joseph von Hammer (London: Printed for the Oriental Translation Fund of Great Britain and Ireland, 1834); A Princess's Pilgrimage: Nawab Sikandar Begum's A Pilgrimage to Mecca, ed. Siobhan sembles stories about the place told by the things that have represented it, historically and imaginatively, to local populations and outsiders alike.

\section{Arabia: Real and Imaginary Geographies}

This collection aims at suggesting new and more nuanced ways of understanding the cultural identity of the Arabian Peninsula by examining some of its most representative things. Employing the innovative lenses of thing theory ${ }^{7}$ and material culture studies, it brings together essays focused on the role of things-from cultural objects to commodities to historical and ethnographic artifacts-in creating an "Arabian" identity throughout the ages. This focus on things allows us to highlight the multifarious interactionscommercial, cultural, and not only-between Arabia and the rest of the world, and think about local identities outside simplifying binaries, as part of a global, nonhierarchical network of relations. This collection is also an attempt to increase the visibility of a culture that has made important contributions to the global cultural heritage. The Arabian Peninsula has a fascinating history that is in process of unveiling in its archeological sites, many of which are today part of UNESCO World Heritage. It also boasts a rich material culture that includes metalwork, earthenware, wood-carved objects, garments and ornaments, ritual objects, nonrepresentational art, and calligraphy-a unique form of traditional Islamic art associated with the Holy Qurān-, and it is home to a
Lambert-Hurley (Bloomington: Indiana University Press, 2007); A Shi'ite Pilgrimage to Mecca, 1885-1886: The Safarnâmeh of Mirzâ Mohammad Hosayn Farâhâni, ed. and trans. Hafez F. Farmayan and Elton L. Daniel (Austin: University of Texas Press, 1990); Jalāl Āl-e Ahmad, Lost in the Crowd (Pueblo, CO: Passegiatta Press, 1985).

6 Alexander Pope, The Rape of the Lock, ed. Cynthia Wall (Boston: Bedford Books, 1998).

7 The term was coined in 2001 by Bill Brown in "Thing Theory," Critical Inquiry 28, no. 1 (2001): 1-22. 
Bedouin culture in which traditional crafts, such as al-Sadu weaving, pottery, and leatherwork, are skillfully employed.

The essays collected here attempt to shed light on the different meanings that the Arabian things gain in different geographical, historical, and cultural contexts, in a survey which spans from the pre-Islamic era to the present day. In doing so, we had to acknowledge that, historically, representations of Arabia have been multifaceted and at times quite at odds with the real place. At one end stand representations that describe Arabia with a certain degree of accuracy: they come both from Western travelers or traders who came in direct contact with the people of Peninsula and from the local populations who developed their own sets of identity markers and symbolic representations. At the other end are representations that emphasize Arabia's riches, magic, sensuality, and exoticism, a fabulous Arabia that has had a lasting impact on the Western imaginary and has been internalized by the local populations today. The Arabian identity that we convey here is a subtle amalgamation of the two: it comprises a fabulous Arabia that has haunted the European imagination for the past three hundred years and a real Arabia that has had its unique history, culture, and traditions. Significantly, after the oil boom, the newly-formed states of the Arabian Peninsula have started a process of nation branding which accounts for both these representations: they have begun assembling their past in museums and heritage sites while at the same time promoting themselves as alluring tourist destinations in a language many times redolent of the Orientalized narratives of the West. As some of our contributors point out, such topoi include exciting desert safaris, exotic destinations, luxurious hotels, opulent retreats, and spellbinding

8 Saree Makdisi and Felicity Nussbaum, introduction to The Arabian Nights in Historical Context: Between East and West, ed. Saree Makdisi and Felicity Nussbaum (Oxford: Oxford University Press, 2008), 1.

9 In Fabulous Orients: Fictions of the East in England, 16621785 (Oxford: Oxford University Press, 2005), Ros Ballaster makes a similar argument about the geographical natural settings, all of which bear testimony to a commercially-driven, self-Orientalizing process.

We have aimed at capturing the tension between these polar opposite representations, as well as highlighting the shared history of the peoples of the Peninsula, by using "Arabian" rather than "Arab" or "Arabic" in the title of this collection. The reference to an "Arabian" identity underlines, first, the geographical confines of our project to the Arabian Peninsula and the material culture produced by the Khaliji, the local population of the area. Second, it also accounts for the intersection between fact and fiction, reality and magic that combine in identifying the place in literary, visual, and cinematic productions. As some of the contributors to this volume argue, the stereotypes about Arabia's wealth, allure, and exoticism started to emerge during the eighteenth century due to a growing interest in the Orient and orientalia. This interest was significantly influenced at the time by the translation of a book that, as Saree Makdisi and Felicity Nussbaum state, "has changed the world on a scale unrivalled by any other literary text."8 First translated in French by Antoine Galland as One Thousand and One Nights (17041717), this book was rendered in English as Arabian Nights' Entertainments (1706-1721), although very few of the tales included in it originated from or were located in the Arabian Peninsula. The book was a composite collection of tales with roots in Persia, Syria, Greece, Turkey, Egypt, India, and even China; however, its English readers were not aware of the complicated history of the manuscript, which started a pervasive process of misattributions and false identifications. From that point on, much of the literature of the time used "Arabia" as an umbrella term that described not one particular location, but many. ${ }^{9}$

inclusivity of the "Orient": "When we speak of the Oriental tale we need to recognize both the force and specificity of those imaginative geographies that emerged as a means of representing Oriental regions and the pressure of generic determinants in narrative not always specific to the culture represented [emphasis added]" (31). 
The reasons for this misleading identification of "Arabia" with a locus of wealth and allure are, of course, not only cultural but also historical: they go back to the Arab conquests of the seventh and eighth centuries that led to the spread of the Arabic language and Islam in geographical areas that extended far beyond the Arabian Peninsula. In other words, the language and the religion of these diverse populations were stronger identifiers than their geographical location at the time the Orientalist literature emerged: in this sense, an "Arab" was a believer in Islam or a speaker of Arabic. As a result, the references to "Arabs" that abound in the Enlightenment literature designated not only the Arabs of the Peninsula but also Persians, Syrians, Ottomans, Egyptians, and a whole host of Muslim populations from northern Africa and the Far East. ${ }^{10}$ Through extension, "Arabia" itself expands both geographically and imaginatively to encompass attributes of plenty, wealth, supernatural, opulence, eroticism, adventure, despotism, exoticism, and desire. This "creative cartography," as one of our contributors describes it, ${ }^{11}$ was subsequently fueled by an extremely productive thread of Orientalist literature and theatrical or operatic productions that inflated and consolidated the extraordinariness of the place, by the exoticizing Orientalist paintings of the nineteenth century and beyond, and, in the twentieth century, by the movie industry and popular culture productions, which capitalized on the Orientalist store of images in representing the place.

10 An older misattribution, this time due to limited knowledge of the area, can be traced back to Herodotus and Pliny the Elder, who used "Arabia" to designate parts of Eastern Egypt, Sinai, and the Negev. To complicate things even more, the Ottoman Empire ruled over much of the Arab world since the conquest of the Mamluk Sultanate in 1517 , hence the common conflation of the Ottomans with the Arabs. Its dissolution in the early twentieth century was followed by the signing of the Alexandria Protocol of 1944 and the formation of the Arab League, which encompasses today twenty-two Arab states. The Arabian Peninsula, which is the focus of our study, includes seven states:Bahrain, Kuwait, Oman, Qatar, Saudi Arabia, the United Arab Emirates, and Yemen.
The consequences of this Orientalizing process have been extensively addressed by Edward Said, Homi K. Bhabha, and Franz Fanon in now-classic works of postcolonial thought. ${ }^{12}$ Started in the latter part of the eighteenth century and described by Said as "a Western style for dominating, restructuring, and having authority over the Orient," the Orientalist discourse "produced" the Orient"politically, sociologically, militarily, ideologically, scientifically, and imaginatively"13 _ as the West's polar opposite. While acknowledging that the Orient is "an integral part of the European material civilization and culture" [emphasis in original], Said points to the fluid "truth" of the Orientalist depictors of the space (i.e., despotism, splendor, cruelty, sensuality, exoticism, or mystery), which are based "not on the material itself," but on imaginative projections that purposefully Orientalize the place.${ }^{14}$ Furthering this analysis, and echoing Fanon's argument about the negative difference encoded in any racial distinctions, Bhabha calls attention to "the alterity and ambivalence of the Orientalist discourse," which vacillates between the recognition and disavowal of "racial and cultural otherness," using it as a mode of identity shaping and colonial control. ${ }^{15}$

The picture these critics paint, however, involves binary oppositions-i.e., civilized vs. barbaric, powerful vs. defeated, rational vs. sensual, sameness vs. foreignness, us vs. the othersthat do not work well when describing the relationship of the Arabian Peninsula with European

\footnotetext{
11 See Holly Edward's chapter, "Creative Cartography: From the Arabian Desert to the Garden of Allah," which concludes the second section of this book. Edward W. Said, Orientalism (New York: Vintage Books, 1979); Homi K. Bhabha, “The Other Question. Stereotype, Discrimination and the Discourse of Colonialism," in The Location of Culture (London: Routledge, 1994), 66-84; and Frantz Fanon, "Racism and Culture," in Toward the African Revolution, trans. Haakon Chevalier (London: Pelican, 1970), 31-44.

13 Said, Orientalism, 3.

14 Ibid., 2 and 67 , respectively.

15 Bhabha, "The Other Question," 71 and 68, respectively.
} 
metropolitan centers. It is not only that Arabia was never a fully-fledged European colony upon which racial, cultural, or historical discriminations could be easily built ${ }^{16}$ but also that it was never in a passive or subaltern position in relation to the European powers in the same way that other colonized territories were: as Allen James Fromherz suggestively put it, "the Gulf was almost always between, but never completely under, particular empires or single civilizations." ${ }^{17}$ More recent projects engaging with the various forms that Orientalism took over time and the neo-Orientalist movements that emerged in the past decades have addressed the place of Arabia within these cultural productions in more nuanced ways. In Fabulous Orients, for instance, Ros Ballaster calls attention to the intersection between materiality and fantasy in constructing the identity of the place: "the English encounter with the East was largely mediated through the consumption of material goods such as silks, indigo, muslin, spices, or jewels, together with the more 'moral' traffic of narratives about the East, both imaginary and

16 Indeed, the representations of the local populations do not contain the tropes of subjectification, impurity, or derision of the colonial stereotype, as defined by Bhabha. Moreover, their dealings with the Ottomans and the British cannot be described as an occupantoccupied relationship in the same way the Arab populations of North Africa, for instance, engaged with the French colonizers (see Fanon, Toward the African Revolution, 66).

17 Allen James Fromherz, "Introduction: World History in the Gulf as a Gulf in World History," in The Gulf in World History: Arabia at the Global Crossroads, ed. Allen James Fromherz (Edinburgh: Edinburgh University Press, 2018), 18-19.

18 Ballaster, Fabulous Orients, 18.

19 Srinivas Aravamudan, Guru English: South Asian Religion in a Cosmopolitan Language (Princeton, NJ: Princeton University Press, 2006), 205. Orientalism," in Enlightenment Orientalism: Resisting the Rise of the Novel (Chicago: University of Chicago Press, 2012), 9.

ethnographic."18 Approaching this phenomenon from a different perspective, Srinivas Aravamudan discusses how Orientalism has led to a process of self-Orientalization by the cultures represented by this strain of literature ${ }^{19}$ and cautions that eighteenth-century "desiring fictions" of Orientalist type "are not colonial propaganda or imperial blueprints, even if they can be refashioned as such after the fact."20 John M. MacKenzie points to the Victorian fascination with Oriental arts and crafts and their current sale in London galleries to wealthy Middle Eastern buyers as a similar search, more than a century later, for "an older, gentler, and [more] appealing world."21 Kristian Davies reminds us that Orientalism is paralleled in the Eastern imaginary by Occidentalism and that both are but natural impulses toward seeing the local populations "for all the richness of their lineage and the pride of their past," ${ }^{22}$ while Christine Peltre describes the "Orient" not as a specific geographical place, but as "the mythic site of all possibilities." ${ }^{23}$ Finally, Valerie Kennedy connects the interest in Orientalism both to the British

21 John F. MacKenzie, "Orientalism in Arts and Crafts Revisited:The Modern and the Anti-Modern: The Lessons from the Orient," in Orientalism Revisited:Art, Land and Voyage, ed. Ian Richard Netton (Abingdon: Routledge, 2013), 123. Other notable reactions to Said's work include Inge E. Boer, ed., After "Orientalism": Critical Entanglements, Productive Looks (Amsterdam: Rodopi, 2003); François Pouillion and Jean-Claude Vatin, eds., After Orientalism: Critical Perspectives on Western Agency and Eastern Re-Appropriations (Leiden: Brill, 2014); and Engin Isin, ed., Citizenship after Orientalism: Transforming Political Theory (London: Palgrave MacMillan, 2015).

22 Kristian Davies, Orientalists. Western Artists in Arabia, the Sahara, Persia, and India (New York: Laynfaroh, 2005). Davies also addresses the perception of a "collective East, a collective 'Orient'” by Western painters, which included very diverse areas, such as Morocco, Algeria, Tunisia, Libya, Egypt, Palestine, Syria, Lebanon, Turkey, Persia, and India, and credits it to their "uniformity of appeal" (13).

23 Christine Peltre, Orientalism in Art, trans. John Goodman (New York: Abbeville Press, 1998), 275. Peltre's 
imperial project, which made Oriental commodities available for consumption to the British subjects, and to the nineteenth-century attraction for popular entertainment like "panoramas and dioramas, shows of exotic peoples, exhibitions of alien cultures, museums and entertainment venues." ${ }^{24}$ Rather than looking at the other spaces of the Near East as the "great complementary opposite"25 of the West, such accounts suggest more nuanced ways of understanding the cultural identity of Arabia not in relation to an other knowledge, but through the things and cultural products that stand for the place, both real and imaginary, and their associated meanings.

\section{Material Culture of the Arabian Peninsula}

The field of material culture studies can provide productive insights into how the things produced, transited, exchanged, gifted, or that constitute the landscape upon which the human subjects live have contributed to the creation of a distinctive Arabian identity over time. As J.D. Prown explains, delving into the material culture of a place means "to discover the beliefs-the values,

argument is rooted in Lisa Nochlin's notion of an "imaginary Orient" put forth in The Politics of Vision: Essays on Nineteenth-Century Art and Society (New York: Harper \& Row, 1989), 33-59. Such views contrast quite sharply with analyses by scholars like Zainab Bitar, for instance, who explains that the British Orientalist art of the nineteenth century developed in the thrall of Realism and often involved the use of the photographic camera to record ethnographic detail. Cf. "Orientalist Art in the Collection of the Sharjah Art Museum," in The Light of the Orient: From the Orientalist Art Collection of H.H. Sheikh Dr. Sultan Bin Mohamed Al Qasimi, ed. Ismael Al-Rifaie (Sharjah: AlQasimi Publications and Sharjah Museum Department, n.d.), 9-27. The relationship between art and photography in nineteenth-century Orientalist paintings is also discussed in MaryAnne Stevens, ed., The Orientalists: Delacroix to Matisse. European Painters in North ideas, attitudes, and assumptions — of a particular community or society at a given time" by paying attention to how "human-made objects reflect, consciously or unconsciously, directly or indirectly, the beliefs of the individuals who commissioned, fabricated, purchased, or used them and, by extension, the beliefs of the larger society to which these individuals belonged." ${ }^{26}$ This is a methodology that focuses on objects as bearers of different meanings in different geographical, historical, and cultural contexts, meanings that need to be unfolded through an active process of contextualization and interpretation. ${ }^{27}$ The strength of this approach comes from its cross- and inter-disciplinary nature: it invites a variety of perspectives-sociological, anthropological, geographical, archeological, historical, museal, and art-related - which illuminate various aspects of the subject-object relation. ${ }^{28}$ Karl Marx's definition of commodities as "social things" and his groundbreaking discussion of commodity fetishism, Raymond Williams' understanding of "cultural materialism" as a means to recover the zeitgeist of a particular historical moment, Marcel Mauss's pioneering studies on gift exchange in primitive societies, and Georg Lukacs' notion of a "reified world" in which commodities stamp their

Africa and the Near East (London: Royal Academy of Arts, 1984), 21-22.

Valerie Kennedy, "Orientalism in the Victorian Era," in Oxford Research Encyclopedia of Literature, August 2017, doi: 10.1093/acrefore/9780190201098.013.226. Said, Orientalism, 58 .

26 Jules David Prown, Art as Evidence: Writings on Art and Material Culture (New Haven, CT: Yale University Press, 2002), 60.

For a brief survey of the field, see Ileana Baird, "Peregrine Things: Rethinking the Global in EighteenthCentury Studies," in Eighteenth-Century Thing Theory in a Global Context: From Consumerism to Celebrity Culture, ed. Ileana Baird and Christina Ionescu (Farnham: Ashgate, 2014), 3-8.

28 For a useful study of the impact of material culture studies on various fields of knowledge, see Arthur Asa Berger, Reading Matter: Multidisciplinary Perspectives on Material Culture (Abington: Routledge, 2017). 
imprints on an individual's consciousness-are only some of the contributions that paved the road to the "Material-Cultural Turn" of the second half of the twentieth century. ${ }^{29}$ Important studies by James Deetz, M.G. Quimby, Thomas J. Schlereth, Ian Hodder, Daniel Miller, Nicholas Thomas, Christopher Tilley, Arjun Appadurai, Igor Kopytoff, Tim Dant and others followed, fundamentally shaping the field. ${ }^{30}$ As suggested by their work, objects can trigger memories and emotions, forge mutual experiences, recall the mindset of individuals or communities long gone, evoke social relations and ceremonial rites, reflect relationships of power, production, or exchange, have their own cultural biographies, shed light on collective practices, and produce symbolic meanings. Applied to virtually every aspect of human life, material culture approaches have expanded to include, beyond things

29 Karl Marx, Capital. Critique of Political Economy, trans. Samuel Moore and Edward Aveling (New York: Modern Library, 1906), 83; Marcel Mauss, The Gift: The Form and Reason for Exchange in Archaic Societies, trans. W.D. Halls (London: Routledge, 1990; first published 1954); Raymond Williams, Culture and Society: 1780-1950 (London: Chatto and Windus, 1958); Georg Lukacs, History and Class Consciousness, trans. Rodney Livingstone (London: Merlin Press, 1967), 100.

James Deetz, In Small Things Forgotten: An Archeology of Early American Life (New York: Anchor Books, 1977); Ian M.G. Quimby, ed., Material Culture and the Study of American Life (New York: W.W. Norton, 1978); Thomas J. Schlereth, Artifacts and the American Past (Nashville: American Association for State and Local History, 1980); Ian Hodder, Symbols in Action: Ethnoarchaeological Studies of Material Culture (Cambridge: Cambridge University Press, 1982); Daniel Miller, Material Culture and Mass Consumption (Oxford: Basil Blackwell, 1987), and his edited collection, Material Cultures: Why Some Things Matter (Chicago: University of Chicago Press, 1998); Nicholas Thomas, Entangled Objects: Exchange, Material Culture, and Colonialism in the Pacific (Cambridge, MA: Harvard University Press, 1991); Christopher Tilley, A Phenomenology of Landscape: Places, Paths and Monuments (Oxford: Berg, 1997); Arjun Appadurai, ed., The Social Life of Things: Commodities in Cultural Perspective (Cambridge: Cambridge University Press, 1998); and Tim Dant, Materiality and Society themselves, landscape, architecture, social memory, and art. ${ }^{31}$

In relation to the Arabian Peninsula, an area strategically placed at the intersection of the trade routes linking the shores of the Indian Ocean and the Horn of Africa to Egypt, Mesopotamia, and the Mediterranean world, this approach is particularly productive as the local populations engaged historically in an intense process of commercial and cultural exchange that led to mutually enriching transfers of both commodities and knowledge. ${ }^{32}$ Unfortunately, although the field of material culture studies has boomed in the past decades, the material culture of the Arabian Peninsula has been largely underrepresented. Overall, current scholarship has engaged only sporadically with the things of Arabia, focusing, instead, on the European interactions and material exchanges

(Berkshire: Open University Press, 2005). Notable studies published in the past decade include Ian Hicks and Mary C. Beaudry, eds., The Oxford Handbook of Material Culture Studies (Oxford: Oxford University Press, 2010); Anne Gerritsen and Giorgio Riello, eds., The Global Lives of Things: The Material Culture of Connections in the Early Modern World (London: Routledge, 2016); and Catherine Richardson, Tara Hamling, and David Gaimster, eds., The Routledge Handbook of Material Culture in Early Modern Europe (London: Routledge, 2017).

See Barbara Bender and Margot Winer, eds., Contested Landscapes: Movement, Exile, and Place (Oxford: Berg, 2000); Victor Buchli, ed., The Material Culture Reader (New York: Berg, 2002); Joëlle Bahloul, The Architecture of Memory: A Jewish-Muslim Household in Colonial Algeria 1937-1962 (Cambridge: Cambridge University Press, 1996); and Anthony Forge, ed., Primitive Art \& Society (London: Wenner-Gren Foundation and Oxford University Press, 1973), among others.

See Michael Edwardes, East-West Passage: The Travel of Ideas, Arts and Inventions between Asia and the Western World (London: Cassell, 1971). As Edwardes points out, these exchanges involved material goods such as textiles and furnishings, rugs, stained glass, mirrors, powder, toiletries, jewelry, metalware, ceramics, perfumes, spices, sweetmeats, sugarcane, and luxury goods, as well as military technology and medical and scientific knowledge. 
with the Islamic East, especially the Ottoman Empire. ${ }^{33}$ Moreover, while modern publications on the Arabian Peninsula include various studies on

33 An example is Yaacov Lev's edited collection, Towns and Material Culture in the Medieval Middle East (Leiden: Brill, 2002), which focuses on the interplay between urban society and material culture in the Ottoman Middle East and includes three cases related to the material culture of the region: the production and spread of paper, textiles, and medicinal substances. See also Finbarr Barry Flood's monograph, Objects of Translation: Material Culture and the Medieval "HinduMuslim" Encounter (Princeton, NJ: Princeton University Press, 2009), which looks at how coins, dress, monuments, paintings, and sculptures helped forge complex transcultural identities in South Asia.

In A History of the World in 10o Objects (New York: Viking Penguin, 2011), for instance, Neil MacGregordescribes an Arabian bronze hand found in a temple from pre-Islamic Yemen (AD 622); this object was an offering to the god Ta'lab Riyam in exchange for the owner's well-being (287-92). For more examples, see Robert G. Hoyland's important study, Arabia and the Arabs: From the Bronze Age to the Coming ofIslam (London:Routledge, 2002).

Lealan Anderson Nunn Swanson, "Historical Considerations in Yemeni Vernacular Architecture: Houses from the Sulayhid Dynasty (439/1047) to the Modern Period" (PhD diss., Ohio State University, 1997); Nancy Um, "Spatial Negotiations in a Commercial City: The Red Sea Port of Mocha, Yemen, during the First Half of the Eighteenth Century," Journal of the Society of the Architectural Historians 62, no. 2 (2003): 178-93, and The Merchant Houses of Mocha:Trade and Architecture in an Indian Ocean Port (Seattle: University of Washington Press, 2009). ing in the Persian Gulf," Journal of the Economic and Social History of the Orient 48, no. 2 (2005): 139-209, and Sea of Pearls: Seven Thousand Years of the Industry that Shaped the Gulf (London: Arabian Publishing, 2012); Victoria Penziner Hightower, "Pearls and the Southern Persian/Arabian Gulf: A Lesson in Sustainability," Environmental History 18 (2013): 44-59, "Pearling and Political Power in the Trucial States, 1850-1930: Debts, Taxes, and Politics," Journal of Arabian Studies 3, no. 2 (2013): 215-31, and "Purposeful Ambiguity: The Pearl Trade and Heritage Construction in the United Arab Emirates," in Cultural Heritage in the Arabian Peninsula: Debates, Discourses and Practices, ed. Karen Exell and Trinidad Rico (London and New York: Ashgate, 2014), 71-84.

ritual offerings, ${ }^{34}$ ancient dwellings, ${ }^{35}$ pearls, ${ }^{36}$ jewelry, ${ }^{37}$ amulets, ${ }^{38}$ Bedouin weaving, ${ }^{39}$ coffee, ${ }^{40}$ incense, ${ }^{41}$ and oil, ${ }^{42}$ they only rarely discuss these

Heather Collier Ross, Bedouin Jewellery in Saudi Arabia (London: Stacy International, 1978); Marie-Claire Bakker, "The Arab Woman Adorned: The Social Role of Jewellery," The Linacre Journal 1 (1997): 47-69; Michael Spink, ed., Islamic Jewellery (London: Spink, 1996) and, more recently, Michael Spink and Jack Ogden, eds., The Art of Adornment: Jewellery of the Islamic Lands, 2 vols. (London: The Nour Foundation in association with Azimuth Editions, 2013).

38 Venetia Porter, Liana Saif, and Emilie Savage-Smith, "Medieval Islamic Amulets, Talismans, and Magic," in $A$ Companion to Islamic Art and Architecture, ed. Finbarr Barry Flood and Gülru Necipoğlu (Hoboken, NJ: John Wiley \& Sons, 2017), 1: 547-604.

39 See Joy Totah Hilden, Bedouin Weaving of Saudi Arabia andItsNeighbours(London:ArabianPublications, 2010), and Patricia Joyce Redding, "Al Sadu Collection: Preserving Bedouin Weaving," in Museums and the Material World: Collecting the Arabian Peninsula, ed. Pamela Erskine-Loftus (Edinburgh:MuseumsEtc., 2014), 333-61. Ralph S. Hattox, Coffee and Coffeehouses: The Origins of a Social Beverage in the Medieval Middle East (Seattle: University of Washington Press, 1985).

41 Nigel Groom, Frankincense and Myrrh: A Study of the Arabian Incense Trade (London: Longman, 1981) is still the reference book on this commodity. More recent studies on frankincense worth mentioning here are Juliet Highet, Frankincense: Oman's Gift to the World (New York: Prestel Publishing, 2006); Françoise AubaileSallenave, "Bodies, Odors, Perfumes in Arab-Muslim Societies," in The Smell Culture Reader, ed. Jim Drobnick (Oxford: Berg, 2006), 391-426; and the excellent chapter by Shimshon Ben-Yehoshua, Carole Borowitz, and Lumír Ondřej Hanuš, "Frankincense, Myrrh, and Balm of Gilead: Ancient Spices of Southern Arabia and Judea," in Horticultural Reviews, Volume 39, ed. Jules Janick (Oxford: Wiley-Blackwell, 2012), 1-76.

See Jill Crystal, Oil and Politics in the Gulf: Rulers and Merchants in Kuwait and Qatar (Cambridge: Cambridge University Press, 1990); David G. Heard, "Development of Oil in the Gulf: The U.A.E. in Focus," in Oil and Regional Developments in the Gulf, ed. Rosemary Hollis (London: Royal Institute of International Affairs, Middle East Programme in association with Division of Research and Studies, Crown Prince Court of Abu Dhabi, 1998), 34-68, and From Pearls to Oil: How the Oil 
objects in relation to their role in constructing a distinctively "Arabian" regional identity. More often, they provide details about the material life of the area within the larger context of the developments in trade, manufacturing, architecture, crafts, and ritual life.

Another category of publications addresses aspects of the life in the Arabian Peninsula that contain references to materiality without making this the main focus of their analysis. For example, H.R.P. Dickson's study, The Arab of the Desert, is a comprehensive account of the Bedouin life in $\mathrm{Ku}$ wait and Saudi Arabia that includes references to local food, tents, furnishings, jewelry, medicines, boat building, pearl diving, Arabian horses, camels, and other domestic and wild animals of the area. ${ }^{43}$ Similarly, Jibrail S. Jabbur's account, The Bedouins and the Desert: Aspects of Nomadic Life in the Arab East ${ }^{44}$ is suggestively organized around four pillars of Bedouin life: the desert (with attentive depictions of its trees, plants, animals, birds, reptiles, and insects), the camel, the tent, and the Arab Bedouin himself, calling thus attention to the central role of the material in the daily life of the Bedouin tribes.

A third category of scholarship includes studies that address more specifically the material culture of the Arabian Peninsula, focusing on its distinctive contribution to the global heritage. Barbara

Industry Came to the United Arab Emirates (Dubai: Motivate Publishing, 2011); Terence Clark, Underground to Overseas: The Story of Petroleum Development Oman (London: Stacey International, 2007), and "Oman: A Century of Oil Exploration and Development," Asian Affairs 39, no. 3 (2008): 388-99.

43 H.R.P. Dickson, The Arab of the Desert. A Glimpse into Badawin Life in Kuwait and Sau'di Arabia (London: George Allen \& Unwin, 1949).

44 Jibrail S. Jabbur, The Bedouins and the Desert: Aspects of Nomadic Life in the Arab East, trans. Lawrence I. Conrad and ed. Suhayl J. Jabur and Lawrence I. Conrad (New York: sunY Press, 1995).

45 Barbara Finster, "The Material Culture of Pre- and Early Islamic Arabia," in Flood and Necipoğlu, A Companion to Islamic Art and Architecture, 1: 87-114.
Finster, for instance, discusses the material culture of the area during antiquity, when Arabia played an essential role in the trade in incense, myrrh, and spices, developed a flourishing handicraft industry, and boasted several architectural landmarks. ${ }^{45}$ Similarly, in An Arabian Collection: Artifacts from the Eastern Province, Grace Burkholder lists an impressive array of everyday, ornamental, and ritual objects collected from the Eastern Province of Saudi Arabia, which is described as a true "archeological wonderland,"46 to highlight the cultural richness of the area. Nancy Um's Shipped but Not Sold: Material Culture and the Social Protocols of Trade during Yemen's Age of Coffee is an important monograph that looks at the networks of commercial exchange developed during the eighteenth century between the Arabian Peninsula and the rest of the world. Traded objects included spices and aromatics, coffee grown in the mountains of Yemen, Arabian horses, food, medicine, furniture, pens, paper, and wax candles —all items that contributed to the emergence of a distinctive Arabian identity during the time. Western Arabia in the Leiden Collections: Traces of a Colourful Past describes a collection of Arabian objects preserved in the Volkenkunde Museum which includes historical artifacts, objects of everyday use, garments, and pilgrim souvenirs, as well as a collection of manuscripts, photographs, and books related to

46 Grace Burkholder, An Arabian Collection: Artifacts from the Eastern Province (Boulder: GB Publications, 1984), 9. The objects mentioned include jugs, bowls, cups, animal figurines, mace heads, copper or bronze mirrors, beads, miniature spouted vessels, incense burners, seals, bracelets, earrings, bone spindles and whorls, storage jars, kitchenware, small glass bottles, seal rings, ear cleaners, mother-of-pearl applicators (used in the past as wands for perfume and to apply khol, a popular black eye makeup), lamps, cookpots, and pearling and net weights. See, also, Margaret S. Graves, Arts of Allusion: Object, Ornament and Architecture in Medieval Islam (Oxford: Oxford University Press, 2018), which contains references to stone incense burners and metalwork in and around the Arabian Peninsula. 
the Gulf area, hosted at Leiden University. ${ }^{47}$ Such studies deepen our understanding of the Arabian Peninsula by calling attention to the importance of its things not only as circulating commodities or exemplars of intellectual history but also as stable signifiers of a place with unique characteristics and social engagements.

Finally, a comparatively better represented category of studies is dedicated to the culture of the museum in the Arabian Peninsula. In the past decade, several studies have focused on the extraordinary post-1970 museum boom, which aimed at creating social cohesion and a sense of national identity in the newly-formed Gulf states. ${ }^{48}$ The opening of the first national museums in Yemen (1971), Oman (1974), Qatar (1975), Kuwait (1983), and Saudi Arabia (1999) is indicative of the growing interest in recovering the past by displaying it in museal exhibits-be they private collections made public, or mega-museums like Mathaf: The Arab Museum of Modern Art and the Museum of Islamic Art in Qatar, or Louvre Abu Dhabi and Guggenheim Abu Dhabi in the U.A.E., to name just a few. In such sites, as Pamela Erskine-Loftus aptly explains, "[t]raditional objects become exemplars for past times that should be venerated and lifeways that should be maintained, as well as symbolism within a constructed collective history and

47 Luitgard Mols and Arnoud Vrolijk, Western Arabia in the Leiden Collections: Traces of a Colourful Past (Leiden: Leiden Publications, 2016).

48 Noteworthy titles include Sonja Mejcher-Atassi and John Pedro Schwartz, eds., Archives, Museums and Collecting Practices in the Modern Arab World (Burlington: Ashgate, 2012); Pamela Erskine-Loftus, ed., Reimagining Museums: Practice in the Arabian Peninsula (Edinburgh: MuseumsEtc., 2013); Karen Exell, ed., Modernity and the Museum in the Arabian Peninsula (Oxon: Routledge, 2016); Pamela Erskine-Loftus, ed., Museums and the Material World cited above; Karen Exell and Trinidad Rico, eds., Cultural Heritage in the Arabian Peninsula cited above; Pamela Erskine-Loftus, Victoria Penziner Hightower, and Mariam Ibrahim Al-Mulla, eds. Representing the Nation: Heritage, Museums, National Narratives, and Identity in the Arab Gulf States (Oxon: Routledge, 2016); and Karen Exell and Sarina Wakefield, identity, and a bastion against certain aspects of globalization." 49 While proudly displaying unique art objects and artifacts, such cultural ventures consistently highlight commonalities among the states in the Gulf Cooperation Council that include "an economic history focused on pearling and trading ... and a cultural background shaped by Islam, Bedouin culture, and transregional tribal identities." ${ }^{50}$ This scholarship focuses on the role of the museum in representing the regional culture of the Gulf states, as well as on the tensions between newly-adopted museum practices and local forms of heritage performance and preservation. Importantly, they all emphasize the crucial role of materiality in the formation of national identities, a scholarly focus that has gained increasing traction in academia in recent years. ${ }^{51}$

Also engaging with the material culture of the Gulf area, past and current exhibitions in the region and beyond show a symptomatic interest in both recuperating the past through collections of local arts, crafts, or historical artifacts and glamorizing it through lavish displays of Orientalist artwork. Originally developed in 2010 by the Saudi Commission for Tourism and National Heritage and the Louvre Museum, the Roads of Arabia touring exhibition has already visited fifteen cities throughout the world, revealing through the objects displayed the

eds., Museums in Arabia: Transnational Practices and Regional Processes (Oxon: Routledge, 2016).

Pamela Erskine-Loftus, "Introduction: Ultra-Modern Traditional Collecting," in Erskine-Loftus, Museums and the Material World, 41.

Karen Exell, "Introduction: Questions of Globalization, Modernity and the Museum in the Arabian Peninsula," in Exell, Modernity and the Museum in the Arabian Peninsula, 6.

$5^{1}$ See, for instance, a recently published collection, Geneviève Zubrzycki, ed., National Matters: Materiality, Culture, and Nationalism (Stanford: Stanford University Press, 2017), which focuses on three key areas through which materiality informs the idea of nationalism: the relationship between objects and national institutions, the role of commonplace objects in shaping a national ethos, and the importance of everyday practices in enacting and embodying the nation. 
diversity of the cultures and civilizations who met within its confines. In 2017, the Lest We Forget exhibition in Abu Dhabi gathered a wide array of tangible and intangible forms of adornment, from garments, jewelry, and weapons to henna, kohl, and fragrance. Simultaneously, Orientalist art is increasingly seen as a financial investment vehicle for new generations of buyers and local governments in the Gulf area, being showcased in the Orientalist Museum in Doha and in the Sharjah Art Museum, or, more recently, in the Majilis and Monda Galleries in Dubai. ${ }^{52}$ Exhibitions of Orientalist paintings have proliferated both in the Arabian Peninsula and internationally, being constant points of attraction for visitors. ${ }^{53}$ Another major cultural event, Les mille et une nuits exhibition, opened in 2012 at the Institute du Monde Arabe in Paris to tell the tales of the Arabian Nights in three hundred and fifty sundry pieces collected from

52 Al Fahidi Festival-The New Orientalists, The Majilis Gallery, Dubai, February 6 to September 1, 2019, http://www .themajlisgallery.com/2016/o1/al-fahidi-festival-neworientalists/; The Orientalist Exhibition, Monda Gallery, Dubai, January 17 to February 27, 2019, https://www .mondagallery.com/collections/orientalist-collection.

For a comprehensive survey of exhibitions of Orientalist paintings in the Middle East, see Mercedes Volait, "Middle Eastern Collections of Orientalist Painting at the Turn of the 21st Century: Paradoxical Reversal or Persistent Misunderstanding?" in Pouillon and Vatin, After Orientalism, 251-71. Outside the Middle East area, important Orientalist exhibitions include Eastern Encounters: Orientalist Painters of the Nineteenth Century, opened in July 1978 at the Fine Art Society (the first major Orientalist painting exhibition) in London; Noble Dreams, Wicked Pleasures: Orientalism in America, 1870-1930, an exhibition launched in 2000 at the Clark Art Institute in Williamstown; The Lure of the East, an exhibition opened at the Tate Gallery in London in 2008; the Orientalist Painting Collection at the Petra Museum, in Turkey; and Marvels and Mirages of Orientalism, an exhibition opened in 2015 at the Montreal Museum of Fine Arts.

To illustrate these various perspectives, see, for instance, John Plotz, "Can the Sofa Speak? A Look at Thing Theory," Criticism 47, no. 1 (2005): 109-18; Jane Bennett, sixty-two museums in sixteen countries. The exhibits included artifacts, rare manuscripts, and modern productions and highlighted the significant impact of Orientalism on art, song, dance, literature, and film.

Another methodological focus of our collection involves employing the innovative lenses of thing theory in approaching literary texts, visual arts, and cinematic productions of and about "Arabia." By proposing a return to things as primary focus of cultural inquiry, thing theory allows for productive discussions about things' agency, consumer culture, fashion fads, scientific curiosity, collecting practices, and things' role in preserving the past or in signaling cultural difference, to name just a few. ${ }^{54}$ Predicated on Heidegger's distinction between objects and things, ${ }^{55}$ thing theory accounts for things' historical and phenomenological context, for their fluid meanings and relations

Vibrant Matter: A Political Ecology of Things (Durham: Duke University Press, 2010); Frank Trentmann, Empire of Things: How We Became a World of Consumers, from the Fifteenth Century to the Twenty-First (New York: HarperCollins, 2016); Jennifer Grayer Moore, Fashion Fads through American History: Fitting Clothes into Context (Santa Barbara, CA: Greenwood, 2016); Barbara M. Benedict, Curiosity: A Cultural History of Early Modern Inquiry (Chicago: University of Chicago Press, 2001); Mark Blackwell, ed., The Secret Life of Things: Animals, Objects, andIt-Narratives in Eighteenth-Century England (Lewisburg: Bucknell University Press, 2007); and Ileana Baird and Christina Ionescu, eds., Eighteenth-Century Thing Theory in a Global Context cited above. Important studies on collecting practices include Roger Cardinal and John Elsner, eds., The Cultures of Collecting (London: Reaktion Books, 1994); Susan M. Pearce, ed., Interpreting Objects and Collections (New York: Routledge, 1994); Silvia Spitta, Misplaced Objects: Migrating Collections and Recollections in Europe and the Americas (Austin: University of Texas Press, 2009); and, more recently, Kevin M. Moist and David Banash, eds., Contemporary Collecting: Objects, Practices, and the Fate of Things (Lanham: Scarecrow Press, 2013). Martin Heidegger, "The Thing," in Poetry, Language, Thought, trans. Albert Hofstadter (New York: Harper Collins, 1971), 161-84. 
with the human subject, for their materiality as well as absence, proposing, thus, a new and more expansive understanding of the human-object interaction:

"You could imagine things as what is excessive in objects, as what exceeds their mere materialization as objects or their mere utilization as objects-their force as a sensuous presence or as a metaphysical presence, the magic by which objects become values, fetishes, idols, and totems. Temporalized as the before and after of the object, thingness amounts to a latency (the not yet formed and the not yet formable), and to an excess (what remains physically and metaphysically irreducible to objects). But this temporality obscures the all-at-onceness, the simultaneity, of the object/thing dialectic and the fact that, all at once, the thing seems to name the object just as it is even as it names some thing else." 56

Understanding the thing as an object-with-adifference refines, thus, one's approach to materiality to include the things' ritual, symbolic, and other construed meanings, as well as their power to shape both the space they inhabit and the human subjects themselves. In his 2003 monograph, The Sense of Things, Brown depicts things as "the congealed facts and fantasies of a culture, the surface phenomena that disclose the logic or illogic of industrial society." ${ }^{\prime 2}$ His attempt to discover the idea of things, as well as the ideas in things, involves a new logic of seeing, one that sheds light on an object's interiority and considers the way things are reflected by the image culture of their time. ${ }^{58}$

\footnotetext{
56 Brown, "Thing Theory," 5.

57 Brown, A Sense of Things: The Object Matter of American

Literature (Chicago: University of Chicago Press, 2003), 4. For more on thing theory, see also by the same author "Object Relations in an Expanded Field," Differences: $A$ Journal of Feminist Cultural Studies 17, no. 5 (2006): 88106, and "Reification, Reanimation, and the American Uncanny," Critical Inquiry 32, no. 2 (2006): 175-207.
}

Given the cultural prominence of the Arabian things in the West's life and imaginary, especially from the eighteenth century onward, when trade with the Middle East underwent a radical growth and the interest in connoisseurship and the culture of collecting started to emerge, this focus on things allows for an exploration of the narratives, myths, and stereotypes associated with the area. Surprisingly, however, in-depth analyses applying this approach to the things of Arabia are quite scarce; among those, a notable contribution is Marina Warner's monograph, Stranger Magic, which explores the "thing-world" of the Arabian Nights through insightful close readings of its most representative tales. ${ }^{59}$ As the author argues, the poisoned books, household goods, furnishings, talismans, speaking body parts, relics, automata, and mechanical devices of the Arabian Nights are magically ensouled, fueling the Occident's imagination with unlimited narrative possibilities while also speaking of a busy trade in exotic objects that familiarized their consumers with remote areas of the world:

"Like Zobeide and Sinbad and Marouf and so many other merchants and travelling traders, active and enchanted things also travel in the bustling trade and traffic of the Mediterranean, the North African coast and the Middle East. This mercantile society, with its many tales of buried treasure and sudden windfalls, and its population of sailors, beggars, shopkeepers, craftsmen, tradesmen and every kind of shopper, endows goods with independent presence and vitality, while their enchanted state recognizably derives from a world of unique treasures on the onehand and a thriving marketinseries and copieson the other." 60

\footnotetext{
58 Brown, $A$ Sense of Things, 1-3.

59 Marina Warner, Stranger Magic: Charmed States and the Arabian Nights (London: Chatto \& Windus, 2011). See also Sophy Kohler, "Stories 'Lodged in Goods': Reading the Thing-Culture of the Thousand and One Nights" (Master's thesis, University of Cape Town, 2017).

6o Warner, Stranger Magic, 200-01.
} 
These "material cultures of connections,"61 as Gerritsen and Riello felicitously have called them, draw attention to the networks of exchange, both real and fictional, that render a thing different when transposed outside its place of origin, or when displayed in museums at a considerable distance in time from its moment of production. Indeed, "[a]s is often the case in cosmopolitan places, other people's things appear in unlikely places, their original meaning or function long forgotten." 62 The many "Arabian" things that fill the Oriental tales of the Enlightenment, for instance, are literally misplaced, being often imports from remote geographical areas that only transited the Arabian Peninsula: such things, however, allow for fascinating insights into processes of transculturation and appropriation with expansive cultural ramifications. These processes highlight, for instance, what Emma Newport calls a thing's "fictility" - the value of a thing as fiction, or the process whereby a society comes to terms with the meaning of an object by reckoning its capacity to sustain fictions about its own origin, travels, forgeries, and innocent or willful misreadings of what it stands for. ${ }^{63}$ Such transpositions of place, time, and function, such misplacements and misattributions, such fanciful tales of belonging, or, on the contrary, such opportunities to preserve and recover a past that would otherwise be forever lost, are particularly relevant in relation to the things of Arabia, whose multiple layers of meaning, individual histories, cultural and commercial imports, and fictional lives are still waiting to be unveiled.

\section{The Things of Arabia: New Perspectives}

As seen from this brief literature survey, there is a scarcity of works that focus on the role played by

\footnotetext{
61 See Gerritsen and Riello, The Global Lives of Things.

62 Fromherz, "Introduction," 4.

63 Emma Newport, "The Fictility of Porcelain: Making and Shaping Meaning in Lady Dorothea Banks's 'Diary Book," Eighteenth-CenturyFiction 31, no.1(Fall 2018): 127.
}

materiality in the formation of an Arabian identity, despite the historical omnipresence of the Arabian things in the daily life of the West through a myriad of commercial and literary channels, and despite the fundamental role played by everyday, traded, gifted, symbolic, or ritual things in the life of local populations. It is our intention to fill in this gap by collecting here new scholarship that elaborates on these networks of exchange from a broader and more inclusive perspective, one that compiles both Western and Middle Eastern views on the material culture of the Arabian Peninsula.

In assembling this collection, we had to be inevitably selective in our choice of both representative things and organizing events. In our view, the two main events that created paradigm shifts in thinking about Arabia are the translation of the Arabian Nights' Entertainments in France (17041717) and England (1706-1721) in the eighteenth century, and the oil boom in the Gulf area in the third decade of the twentieth century. Each of these events radically changed the way the identity of the place was perceived both in the Western and in the local imaginary, giving rise to enduring representations of "Arabia" that were subsequently internalized and used as identity markers by the peoples of the Peninsula. These two phenomena also illustrate the organic, necessary interdependence of economic and cultural events in processes of identity formation and regional and national branding. While historical events occur within and are determined by economic contexts, they do not tell the full story of people's perception of themselves and of their place in the global imaginary. Place, language, religion, ethnicity, customs, aesthetics, history, and the narratives people construct about themselves or that are imposed upon them play essential roles in forming a group's identity. Although these representations often involve

The author expands here on Elizabeth Kowaleski-Wallace's discussion of porcelain's metaphoric potential in "Women, China, and Consumer Culture in EighteenthCentury England," Eighteenth-Century Studies 29, no. 2 (1995):153-67. 
binary oppositions that place us versus the others, these differences should be proudly embraced rather than seen as hierarchical divides. From this perspective, the things that organize the material and spiritual life of a particular people allow for a new and less biased story to be told, a story that highlights a group's distinctiveness, its participation in processes of material and cultural exchange, and its unique place in the global family of nations.

We start this collection, therefore, with a section on Arabia of the old that focuses on things that have been considered as hallmarks of the area, being intensely traded throughout its history: frankincense, pearls, and dates. In "Frankincense and Its Arabian Burner," William Gerard Zimmerle considers frankincense and myrrh as the principal reference points for Arabia in the Mediterranean world during the Hellenistic, Byzantine, and Islamic periods. The author links the botanical and chemical study of frankincense gum resins and oils to the philological study of aromatic lexicography in Islamic, Mesopotamian, and Classical sources. By analyzing the material culture that was left behind, such as incense burners or alabastra and its residues, Zimmerle demonstrates that incense relays of the "Spice Trade" and maps the spread of frankincense as an Arabian luxury commodity from the southern Arabian Peninsula to the Mediterranean area. By considering scents as a crucial but little analyzed part of material culture, the author delves into old and current practices associated with the use of incense in the Arabian Peninsula and beyond. As he compellingly argues, when Westerners envision Arabia, the thought of frankincense comes immediately to their mind due to the entangled memories of this scent, which are deeply grounded in Classical mythology and Christian religious practices.

In "The Tyranny of the Pearl: Desire, Oppression, and Nostalgia in the Lower Gulf," Victoria Penziner Hightower examines the history of the pearl, an object that looms large in the construction of identity in the region. Employing the Kantian notions of thing-in-itself and thing-as-used, and the heritage studies notion of thing-as-remembered, the author provides an account of the pearl's history that highlights its reality, trade value, and symbolic meaning in the memory of the local populations. Using the British India Office Records to substantiate its past and popular and academic sources to assess its present, Hightower addresses the constructions and reconstructions of the significance of the pearl in the daily life of the people of the lower Gulf area. As the author argues, pearling has enabled the Trucial States to assert their identity on the global stage by constructing a national narrative within which the pearl was both a way to access the global economic market and a tyrannical symbol of destitution before the oil boom. Thus, the pearl is intimately bound with processes of identity formation: as the author suggestively states, it entered the commercial and heritage lexicon as "an iconic symbol of a past of struggle and a future of boundless prosperity."

Eran Segal's chapter, "Palm Dates, Power, and Politics in Pre-Oil Kuwait," examines another thing essential to the construction of an Arabian identity: the date palm. Commonly identified as a symbol of national heritage in all Gulf countries, the palm tree was in pre-oil times not only a source of food and building material but also a way of building social relations and economic wealth. This chapter argues that one of the keys to understanding the power of Kuwait's ruling Sabah family in the twentieth century lies in its economic strength, which depended greatly on this staple commodity. From the 1830 os onwards, the Sabah family gradually purchased or took control of extensive date plantations in southern Iraq, being able to build up an economic power base. The dates were both a source of wealth and a political tool in the region, playing an important role in the Sabah family's interactions with the British and in the process of state formation in Kuwait. By delving into the complex social, cultural, and economic significance of dates in the Arabian Peninsula, in general, and in the history of Kuwait, in particular, this chapter illustrates the essential role played by 
"material powers" 64 in processes of capital accumulation and nation-building.

The second section of our collection, Imagining Arabia: Exotic, Fabulous, and Misplaced Things, focuses on the process of "Orientalizing" Arabia, which started during the eighteenth and nineteenth centuries and produced lasting, albeit to a large extent inaccurate, representations of opulence, magic, and exoticism up to the present day. Here, our contributors focus on things inadvertently associated with the Arabian Peninsula due to its intense commercial contacts with the West, a process that led to the proliferation of visual and narrative depictions of a loosely defined "Arabia" during the eighteenth century and beyond. While many of the commodities traded only transited this area, and much of the art and literature depicting "Arabia" was not confined to the Arabian Peninsula per $s e$, things like exotic fruit and spices, lavish garments and jewelry, refined beverages and food, exotic harems and bazaars, or, in the fictional realm, flying carpets, magic lamps, magnificent palaces, and powerful jinns - increasingly became signifiers of "Arabia" as a place of wonder, luxury, and adventure. The first chapter in this section, "Circulating Things, Circulating Stereotypes: Representations of Arabia in Eighteenth-Century Imagination," looks at the process of rendering "Arabia" through the things that stand for this place as symptomatic of the eighteenth century's redefinition of the other spaces in ways that often give rise to stereotypes or, to use Edward Said's words, "imaginative geographies"65 that coalesce into prejudiced attitudes toward the other. Here, the author challenges some of these interpretations by exploring the mechanism of stereotyping in relation to the Arab world outside a colonial lens, and outside a political rendering of the stereotype. As Baird explains, Arabia's things-from spices and perfumes to coffee, dates, garments, and pearls-circulated

64 Patrick Joyce and Tony Bennett, "Material Powers: Introduction," in Material Powers: Cultural Studies, History and the Material Turn, ed. Patrick Joyce and Tony Bennet (Abingdon: Routledge, 2010), 1-22. outside their place of origin on commercial routes that enriched the Western world and, at the same time, disseminated narratives, myths, and stereotypes whose traces can still be found in our culture today. By looking at these accounts as a form of knowledge based on a distant origin of truth which was altered, embellished, or refined in the process of its circulation, the author argues that such stereotypes enrich, rather than distort, our knowledge of Arabia, and thus participate in an ongoing process of identity formation whose tropes have been internalized by the oil-rich countries of the Gulf in productive ways.

In "Who Will Change New Lamps for Old Ones?': Aladdin and His Wonderful Lamp in British and American Children's Entertainment," Jennie MacDonald focuses on the transporting spectacle of productions such as John O'Keeffe's 1788 play, the 1826 Drury Lane opera, and later pantomime, toy theater, and cinematic versions of the Arabian tale. Reliant on material elements such as the magic ring and lamp, and scenic and costume properties evocative of Arabian exoticism, early nineteenth-century productions celebrate concepts of curiosity, wonder, and childhood innocence while offering an imaginative representation of "Arabia" to a Romantic audience. Employing Dongshin Chang's notion of interculturalization, ${ }^{66}$ the author discusses the blurring effect of British Orientalism, which combined British renderings of a fantastical East with elements of Chinese, Arabic, Ottoman, and North African cultures, as well as twentieth-century renditions of the tale in American cinematography which, in turn, perpetuated an "Arabian" look derived from Orientalist props and imagery. Thus, the author explores how Aladdin's lamp has become over time a shorthand for wish-fulfillment, imbuing "Arabia" with lasting qualities of wonder and exoticism and solidifying Romantic stereotypes of the place.

\footnotetext{
65 Said, Orientalism, 49.

66 Dongshin Chang, Representing China on the Historical London Stage: From Orientalism to Intercultural Performance (New York: Routledge, 2015), 1.
} 
By expanding this argument to various manifestations of Orientalism in visual culture and beyond, in "Creative Cartography: From the Arabian Desert to the Garden of Allah," Holly Edwards explores the power of things to fashion a personal, communal, or national self through several cover stories. The author starts by examining two of Jean-Léon Gérôme's best-known paintings, Arabs Crossing the Desert and The Snake Charmer, which have come to epitomize an "imaginary Orient,"67 corroborating Said's thesis of colonial power with visual evidence. Then, she delves into the history of Robert Hichens' novel, The Garden of Allah, which became a hugely successful Broadway play and then a film of the same title, where "real Arabs," elaborate stage props, and evocative consumer products became vehicles for romance, fueling a booming entertainment industry. A final iteration of Orientalism that she explores is the Ancient Arabic Order of the Nobles of the Mystic Shrine, a secretive cohort within the larger order of Freemasonry who fabricated for themselves an Arabized identity through extravagant parades and pilgrimages intended to expand Shrine membership. In telling these cover stories, the author uses the notion of "creative cartography" to describe the process of "mapping, picturing, and narrativizing the world around and through self/other, here/there, and now/then" and argues that making, owning, or viewing arts or artifacts are modes of place-making and identity fashioning with cascading global ramifications. From this perspective, the Arab participation in modern museum culture is seen as a way to revisit and reclaim diverse individual and collective identities embedded in the things representing "the Orient" and the vaguely-defined "Arabian desert."

From the things of the imagination, the third section of the book moves on to things that functioned historically as "emblems" of Arabia for locals and travelers alike: the falcon, the keffiyeh, and al-Sadu weaving. Yannis Hadjinicolaou's chapter, "Kinetic Symbol: Falconry as Image Vehicle in the

67 Nochlin, “The Imaginary Orient," 33.
United Arab Emirates," demonstrates how the iconic afterlife of Arab falconry was crafted in the longue durée through specific visual strategies. This afterlife is narrated by the author in a nonlinear way, from Emperor Frederick II of Hohenstaufen to Sheikh Zayed bin Sultan Al Nahayan, by employing Aby Warburg's concept of "image vehicle,"68 a concept which traces lines of continuity among various historical periods through the migration of images. The author argues that falconry images are "image vehicles" par excellence and uses a broad iconographic tradition to show how ruler and falcon are often associated to suggest sovereign power. Describing the falcon as a national symbol of the U.A.E., he connects this symbol to Sheikh Zayed, the founding father of the Emirates, and to the local Bedouin culture within which it was employed as a means for survival in the desert. By exploring Western art and photographic evidence, as well as work by contemporary artists from the area, Hadjinicolaou argues that the falcon has been elevated to an iconic symbol by the Emiratis, being handed down from one generation to another as a form of heritage that has helped craft for themselves a distinctive identity within the Arabian Gulf countries.

In "Al-Sadu Weaving: Significance and Circulation in the Arabian Gulf," Rana Al-Ogayyel and Ceyda Oskay explore the traditional practice of nomadic weaving that is still carried out by Arab women in Kuwait, Saudi Arabia, the U.A.E., Bahrain, Qatar, and other Gulf countries. As the authors argue, the symbols used in al-Sadu have a wide variety of functions-from tribal identity markers and means of inter-tribal communication to forms of social participation and artistic selfexpression. As such, they indicate that women were very much part of the public sphere in the Arabian Peninsula in the past, which challenges existing perceptions about Arab women's limited participation in the social life. Moreover, given

68 Aby Warburg, Werke in einem Band [Works in a volume], ed. Martin Treml, Sigrid Weigel and Perdita Ladwig (Berlin: Suhrkamp, 2010), 636-37. 
that the nomadic tribes of the Gulf did not keep written records, the textiles became a means of record keeping through their symbols, which reflect social customs and local traditions. In the form of the Bedouin tent, or bayt, al-Sadu also embodies the idea of a soft and portable home that can adapt in relation to different landscapes and social contexts. Thus, the authors trace the history of al-Sadu weaving, the meaning of its symbols, the trade it facilitated, and the social and cultural significance of this practice for current designers in the Middle East and beyond.

One of the most powerful symbols of Arabness, the keffiyeh bears, nevertheless, mixed connotations of Arab pride and political controversy. In "Head Coverings, Arab Identity, and New Materialism," Joseph Donica examines the symbolic significance of the keffyeh, a traditional head covering primarily for men that used to protect them from sun and wind in the Arabian desert. Although in the Gulf area the keffiyeh is an object that ties men back to their Bedouin past, this object has often been politicized, as seen in recent controversies over non-Arabs wearing the keffiyeh as a show of solidarity with the Palestinian fight or for simply being fashionable. By using Ian Hodder's notion of human-object entanglement and new materialist views that reassert the agency of things, the author debates whether wearing another culture's object is an unfitting act of appropriation or an acceptable expression of cultural appreciation. As Donica suggests, by disentangling the keffiyeh from the controversies that surround it, we may reposition it as a social unifier, a cultural symbol, and a fashion staple for the Arab people.

In the last section of our collection, Post-Oil Arabia: Things, Memory, and Local Identity, the contributors focus on the transformative impact of the Gulf oil on the newly-formed nation-states of the Arabian Peninsula. In their view, things that evoke the past, or "memory-objects," are active participants in processes of recovery and preservation of a people's history and cultural identity. This tension between past and present, heritage and commodification, is addressed in the chapter
"Written in Silver: Protective Texts from Inner Oman," where James Redman discusses the significance of inscribed medallions known as kirsh kitab, powerful objects that lost their past protective value, being currently hawked in shops and tourist markets as souvenirs and collectibles. Crafted to either be worn around a woman's neck or placed at home near a bed, these objects used to guard their owners against the ravages of a specific jinniya, Umm Al Subyan, through the divine language of the Qurān inscribed on them. In this chapter, the author looks at these amulets in the broader context of the Omani silver trade and discusses what and how they communicate as texts written by unlettered men for unlettered women. The author regards the imprecisions of the texts imprinted on kirsh kitab as mnemonic faults due to the limitations of pre-1970s Omani education and to their both textual and recitational nature, and he likens them with errors commonly found in the manuscript culture. In this analysis, the texts on the kirsh kitab become a vehicle for grasping the time, place, and society in which they were created, while the circumvoluted history of the amulets illustrates changes in traditions that have relegated them from protective symbols to personal adornments, transportable wealth, family mementos, or tourist souvenirs.

In "Cradle to Grave: A Life Story in Jewelry," Marie-Claire Bakker and Kara McKeown explore the significant role played by ornaments among the people of the Arabian Gulf, as revealed by the numerous carnelian beads, gold and silver jewelry, and splendid Hellenistic and Sasanian craftsmanship found in archaeological sites throughout the Peninsula. Using oral history case studies, ethnographic fieldwork conducted in the early 1990s in Bahrain and Saudi Arabia, and more recent research done in the U.A.E., Bahrain, Kuwait, and Oman, the authors argue that jewelry articulates every major event in an Arab woman's life, from birth to marriage to motherhood to death. While tastes have evolved with each generation, the social role of jewelry has remained relatively stable, expressing social status and a complex matrix of 
reciprocal exchange relationships that make an Arab woman's jewelry an intrinsic part of her identity. As the authors point out, the display and exchange of jewelry among the Khaliji women reinforce a sense of personal and national identity, solidify community ties, and ensure generational continuity.

Finally, in the chapter "Cine-Things: The Revival of the Emirati Past in Nojoom Alghanem's Cinemascape," Chrysavgi Papagianni explores the important role that material culture plays in defining contemporary Emirati identity as reflected by the work of the most acclaimed Emirati female director, Nojoom Alghanem. By employing the notion of "cine-things," the author examines several objects that help shape a local identity-from landscape to vessels to medicines to rugs-and counterpoises them to the transformative thing of oil. In the author's view, Alghanem's film, Hamama, presents things as carriers of memory meant to counteract the annihilating forces of globalization symbolized by oil, an all-encompassing presence defining, to a large extent, the newly-formed Gulf states and their citizens. As Papagianni maintains, positioning these objects at the center of narration allows for building new relationships between humans and things which resist current stereotypes associated with the Emirati identity and offer an alternative understanding of the country and its people.

Hülya Yağcıoğlu's afterword aptly concludes this collection by dwelling on the role of the museum in forging a regional and national identity for the Gulf countries. For the new generations of Khalijit, born into cultures of overconsumption brought by post-oil wealth and rampant globalization, museums represent a way of preserving their past while also asserting their collective and local identity. The heritage revivalism manifest in many of the new nations of the Arabian Peninsula, which boast the most extraordinary museum-building boom in history, becomes, thus, not only a way of forging connections with their pre-oil past but also a form of symbolic and material investment that inscribes their distinctive place on the world's cultural and touristic map.

As evidenced by this brief outline, this collection is both interdisciplinary and cross-historical, involving the combined experience of scholars from diverse fields of study (anthropology, history, ethnography, museology, literary and film studies, and art history) and covering diverse historical periods. It is an endeavor that aims at starting a much-needed dialogue among the diverse cultures of the Arabian Peninsula, as well as repositioning them within the significant output of literature, art, film, and scholarship about "Arabia" produced by the West. We hope that the collective knowledge of the fifteen scholars who have contributed to this volume and the diversity of the perspectives presented here will help fill in existing gaps in scholarship, dispel persistent stereotypes about the area, and stimulate new thinking about a culture whose distinctive patterns of trade and cosmopolitanism have pollinated the world with lasting myths, knowledge, and, last but not least, things of beauty.

\section{Note on Transliteration}

This book follows the transliteration guidelines established by the International Journal of Middle Eastern Studies. In Chapter 10, original Arabic was kept for text comparison. 